\title{
Detailed Analysis of Texas's Manufactured Housing Growth and Competition
}

\author{
Hisham Said $^{1 *}$ and Jonathan Bartusiak ${ }^{2}$ \\ ${ }^{1}$ Assistant Professor, Department of Civil Engineering, Santa Clara University \\ ${ }^{2}$ Graduate Student, Department of Civil Engineering, Santa Clara University \\ ${ }^{*}$ Corresponding author's e-mail: hsaid@scu.edu
}

\begin{abstract}
Manufactured homes provide a cost-effective alternative for satisfying the growing housing needs. Despite the industry commitment for improvement, manufactured home constitute small share of satisfying the housing demand. Supporting the future growth of this industry through public policy advocacy cannot be achieved without evaluating its historical production and demand trends. Available data from professional and governmental sources lack the ability to provide a granular picture of the characteristics of the industry's manufacturers, customers, and product. Accordingly, this paper attempts to fill this gap by analyzing the available license record data for the manufactured homes in the state of Texas that cover the years from 1982 to 2015. The raw data included around 913,663 records of homes ownership and manufacturing. The data analysis included three main tasks: 1) data processing to integrate this large amount of data and eliminate outliers; 2) analyzing the competition characteristics of Texas's manufactured housing market using descriptive entry and exit metrics; and 3) analyzing demand characteristics of manufactured homes in terms of their physical requirements the relations between their demand volume and inventory times. The conclusions of this paper would provide a more detailed understanding of the manufactured housing industry to support its growth as a viable costeffective housing option.
\end{abstract}

\section{KEYWORDS}

Manufactured homes, competition analysis, market entry/exit, industry supply chain

\section{INTRODUCTION}

The housing market is characterized by the diversity of its products, in terms of quality, construction techniques, materials, and prices. Like similar construction sectors, housing contractors have consistently been evaluating innovative materials and design systems to improve the efficiency, sustainability and cost-effectiveness of the industry. As a result of these early efforts, prefabricated mobile homes were introduced as an efficient and affordable housing alternative that were produced in large volumes in factory controlled environment. In support of these efforts, the U.S. Department of Housing and Urban Development (HUD) performed a set of studies to investigate the benefits of mobile homes and study structural and material requirements to improve their quality (NAHB 1998, CHR 2000). The result of these studies is the development of the federal HUD-code for mobile homes that enforced safety and quality 
requirements similar to the site-built homes. The industry reacted to the code by changing the name of the mobile homes to be manufactured home (also called HUD-code homes) to help eliminate its old reputation of low quality.

Manufactured housing industry has have limited and declining market share, despite the promising economic advantages and improving quality standards of manufactured homes. Nearly a decade before the downturn of the housing construction that associated with the recession of 2008, manufactured housing production began a lengthy decline, which followed a period of easy credit availability for the conventional housing. Since reaching its peak at 374,000 new units in 1998, manufactured home placements have fallen by nearly 90 percent (USCB 2013-a). During the last decade, manufactured housing placements have averaged less than one quarter of the annual production during the last three decades. Manufactured home placements declined from 20.2 percent of the total housing market in 1998 to 7.4 percent in 2012 (USCB 2013-b). Different speculations were proposed for the decline and the halted recovery of the manufactured housing industry, but they lack scientific methodologies and the support of rigorous data.

Manufactured homes were the subject of diverse research studies that investigated their construction systems and operations, as well as homeowner attitudes. First, a series of HUDsponsored studies were conducted to advance the building systems and manufacturing processes of manufactured homes (US-HUD 1994, US-HUD 2002, US-HUD 2000, US-HUD 2001). Second, other researchers investigated the management of detailed homes factory operations, (Barriga et al. 2005, Jeong et al. 2006, Mehrotra et al. 2005, Abu Hammad et al. 2008), and manufactured homes mass customization (Nahmens I. and Bindroo). Third, a group of industry research studies were performed to analyse market structure, stakeholders, historical performance, and challenges (Vermeer and Louie 1997, US-HUD 1998, US-HUD 2003). Despite the contributions of previous research studies, there is still a need for a detailed analysis of the manufactured housing industry that would expand the current understanding of manufactured homes and their fabricators. Previous studies depended heavily on aggregated industry data that are mainly available from the U.S. Census Bureau in the form of macro geographic representations (i.e. state data). These macro-data don't allow detailed industry and market analysis that can provide a deeper understanding of the product characteristics of manufactured homes and the competition between their fabricators.

Accordingly, this paper presents a preliminary detailed study of the trends and attributes of the manufactured housing industry using a large sample of micro raw data of a large geographic area. The study depends on available licensing data of manufactured homes in the state of Texas that provide detailed information on homes manufacturing and sale between 1982 and 2015. Texas is one of the largest states in the U.S. manufactured housing industry, which has contributed an average of $14.3 \%$ of the total national production and received $12.7 \%$ of the national home shipments. Accordingly, the large size of the Texan manufactured housing market can justify the generalization of the results of this study to the national level. The following sections describe in details the collected raw data, data processing, market competition analysis, and the analysis of the market requirements.

\section{STUDY RAW DATA}

The raw data were obtained from the home ownership record database that is downloaded from the Texas Department of Housing and Community Affairs. The data covers the period between 
1983 and 2015, except for April 1993 that was not available from the website. Each entry in the data represents the ownership record for every new or used manufactured home that was placed in Texas. Each ownership record includes the following categories of data fields: 1) the unique identification codes of each section of the home; 2) the dimensions and weights of every home section; 3) the manufacturer data that include the identification number and address; 4) the seller data that include the name and address; and 5) the buyer data that include the name and address. The data files were downloaded for every year and combined in a large spreadsheet file that included 913,663 records and consumed about $280 \mathrm{MB}$ of memory.

\section{DATA PROCESSING}

The purpose of processing the raw data is to identify relevant information of the recorded homes and their manufacturers in a way that eliminates any data inconsistencies or corrupted entries. Two Visual Basic for Applications (VBA) macros were developed to process the data into four main data sets: 1) the list of manufacturers that are obtained from the raw data using both their identification numbers and zip codes as unique identifiers; 2) the time series of the annual number of homes supplied from each manufacturer; 3 ) the list of all manufactured homes that were placed in Texas that are identified using both the label and identification number of their first section (module); 4) the time series of a set of metrics to track the annual average attributes of the manufactured homes, such as the area, weight, and inventory time (difference between manufacturing and sale dates). Data processing resulted in identifying 889,740 unique manufactured homes that were supplied from 953 unique manufacturers. The difference between the initial number of home licenses $(913,663$ records) and the number of unique homes $(889,740)$ can be attributed to the reselling and relicensing some homes.

\section{MARKET COMPETITION ANALYSIS}

Texas's manufactured housing data is analysed to assess the competition attributes and dynamics between the home manufacturers from Texas (locals) and those out of the state (foreigners). The conjecture here is that local and foreign manufacturers should have a fair perfect competition (Einav and Levin 2010) between them, considering the mobile nature of the manufactured homes. Competition can be initially assessed by examining the number of manufacturers and supply volumes of manufactured homes in Texas. Local manufacturers contributed the largest share of new home supply in Texas. The manufactured home supply in Texas follows the same historical national trends as reported by the US Census Bureau (USCB 2013-a). The contribution of local manufacturers to Texas's home supply ranged between $68.5 \%$ and $93.6 \%$. However, the number of local manufacturers involved in Texas manufactured housing market represented a lower share ranging between $26.6 \%$ and 52.6\%. That constitutes an initial assessment of imperfect competition between local and foreign home manufacturers in the regional market in Texas. However, absolute values of production and number of manufacturers are not sufficient to understand the market competition. Relative descriptive dynamic metrics such as entry and exit rates (Timothy et al. 1988) should be analysed to get a better understanding of the competition between local and foreign home manufacturers. This study utilizes a set of entry and exit metrics (Dunne et al. 1988, Prieger and Connolly 2013) as an alternative descriptive way to stylized results from regression analysis (Geroski 1995). The next sections explain the formulation of these entry and exit metrics and their observations in the collected data, followed by final remarks on the competition characteristics of manufactured housing industry in Texas. 


\section{Market Entry}

Market entry refers to the incident and easiness of manufacturers to enter into the market (called entrants in this instance) and compete manufacturers with previous presence in the market (called incumbents). To assess the market entry of the analysed manufactured housing industry in Texas, 4 metrics are examined for the collected data in every year t: 1) number of entrants $\left.\left(N E_{t}\right) ; 2\right)$ entry rate $\left.\left(E R_{t}\right) ; 3\right)$ entrants' share $\left(E S H_{t}\right)$; and 4$)$ entrant's relative size $\left(E R S_{t}\right)$. First, a manufacturer is identified as an entrant in a year $\mathrm{t}$ if it did not supply any home to the state in the previous year t-1. As such, Figure 1-a shows the number of entrants over the years for all manufacturers, local manufacturers (Texas), and foreign manufacturers (other states). Second, entry rate $\left(E R_{t}\right)$ in year $t$ is calculated as the ratio between the number of entrants in year $\mathrm{t}\left(N E_{t}\right)$ and the total number of manufacturers in year t-1 $\left(N T_{t-1}\right)$. Figure 1-b depicts $E R_{t}$ for all manufacturers, local manufacturers, and foreign manufacturers. The third and fourth metrics $\left(E S H_{t}\right.$ and $\left.E R S_{t}\right)$ are utilized to assess the magnitude of the market entrants relative to the whole industry and existing incumbent manufacturers, as shown in Figure 2. The entrants' share $\left(E S H_{t}\right)$ is calculated as the ratio between number of manufactured homes supplied by the entrants $\left(Q E_{t}\right)$ and the total number of homes supplied by all manufacturers $\left(Q T_{t}\right)$ in year t. Finally, entrant's relative size is calculated using Equation 1.
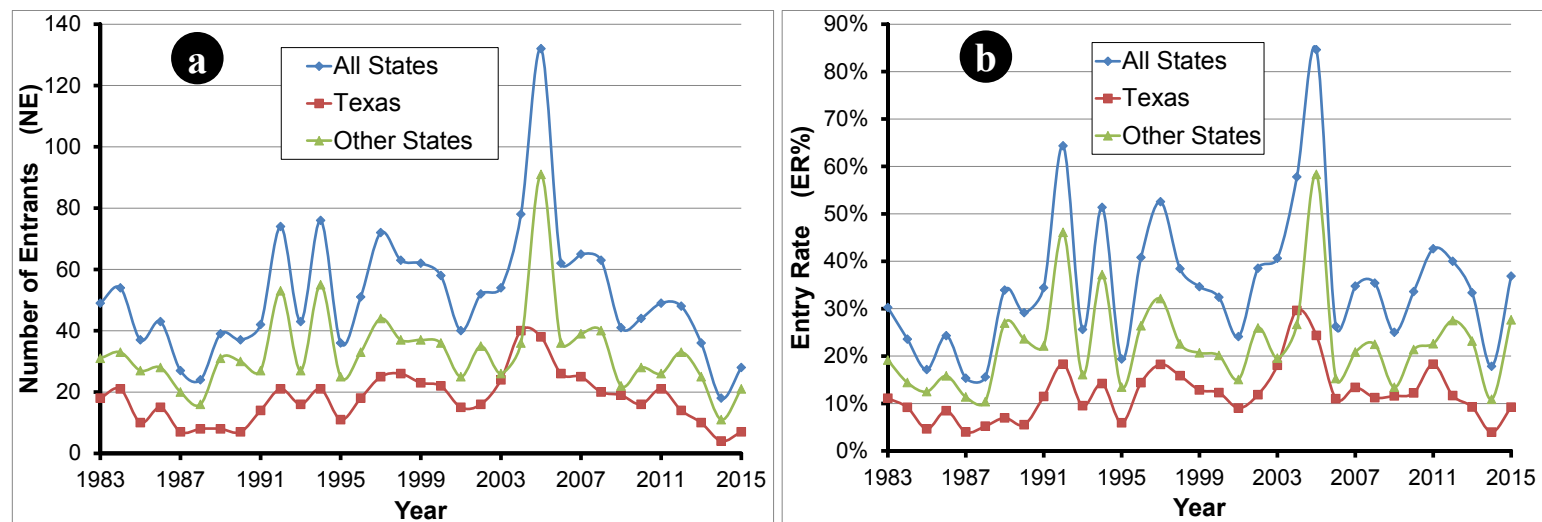

Figure 1. Texas market entry for home manufacturers: a) number of entrants; b) entry rate.
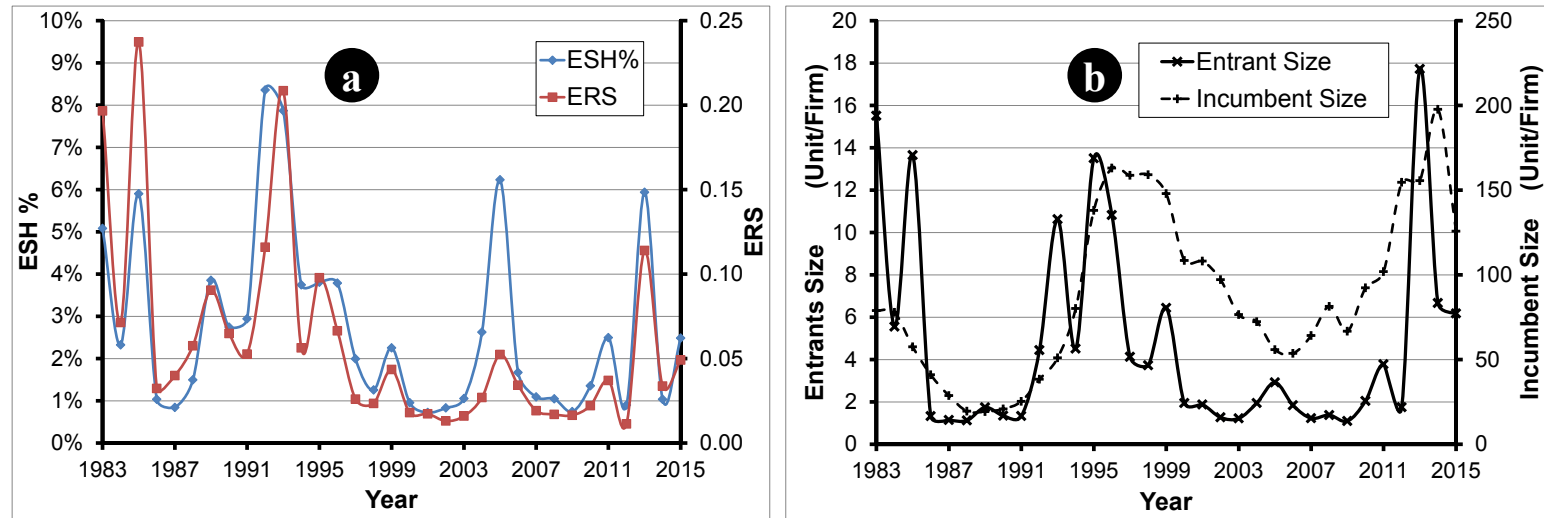

Figure 2. Characteristics of manufactured home market entrants in Texas: a) entrants' share (ESH) and their relative size (ERS); b) size comparison between entrants and incumbents. 
$E R S_{t}=\frac{Q E_{t} / N E_{t}}{\left(Q T_{t}-Q E_{t}\right) /\left(N T_{t}-N E_{t}\right)}$

\section{Market Exit}

Market exit is the attribute of the industry that refers to the extent and causes of departure of the manufacturers from a studied market. Similar to entry, market exit is analysed using four measures: 1) number of exiters $\left.\left(N X_{t}\right) ; 2\right)$ exit rate $\left.\left(X R_{t}\right) ; 3\right)$ exiters' share $\left(X S H_{t}\right)$; and 4) exiter's relative size $\left(X R S_{t}\right)$. First, a manufacturer is identified as an exiter in a year $\mathrm{t}$ if the firm did not supply any home to the state in the current year $t$ after a productive year in the year before $t-1$. Figure 3-a shows the number of exiters as a time series for all, Texas-local, and Texas-foreign manufacturers. Second, exit rate $\left(X R_{t}\right)$ in year $\mathrm{t}$ is calculated as the ratio between the number of exiters in year $\mathrm{t}\left(N X_{t}\right)$ and the total number of manufacturers in year $\mathrm{t}-1\left(N T_{t-1}\right)$, and is illustrated in Figure 3-b. Third, the exiters' share $\left(X S H_{t}\right)$ is calculated as the ratio between number of manufactured homes supplied by the exiters $\left(Q X_{t}\right)$ and the total number of homes supplied by all manufacturers $\left(Q T_{t}\right)$ in year t. Fourth, exiter's relative size $\left(X R S_{t}\right)$ is calculated using a variant of Equation 1 that depends instead on exiters' home supply $\left(Q E_{t}\right)$ and the number of exiters $\left(N E_{t}\right)$.
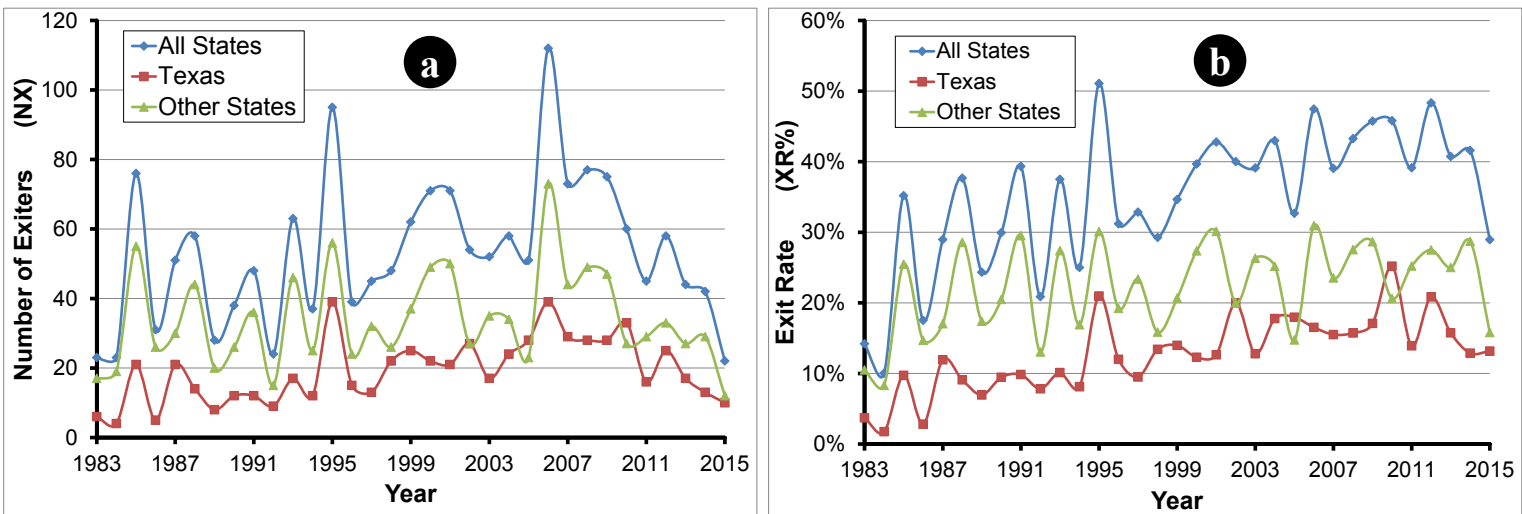

Figure 3. Texas market exit for home manufacturers: a) number of exiters; b) exit rate.
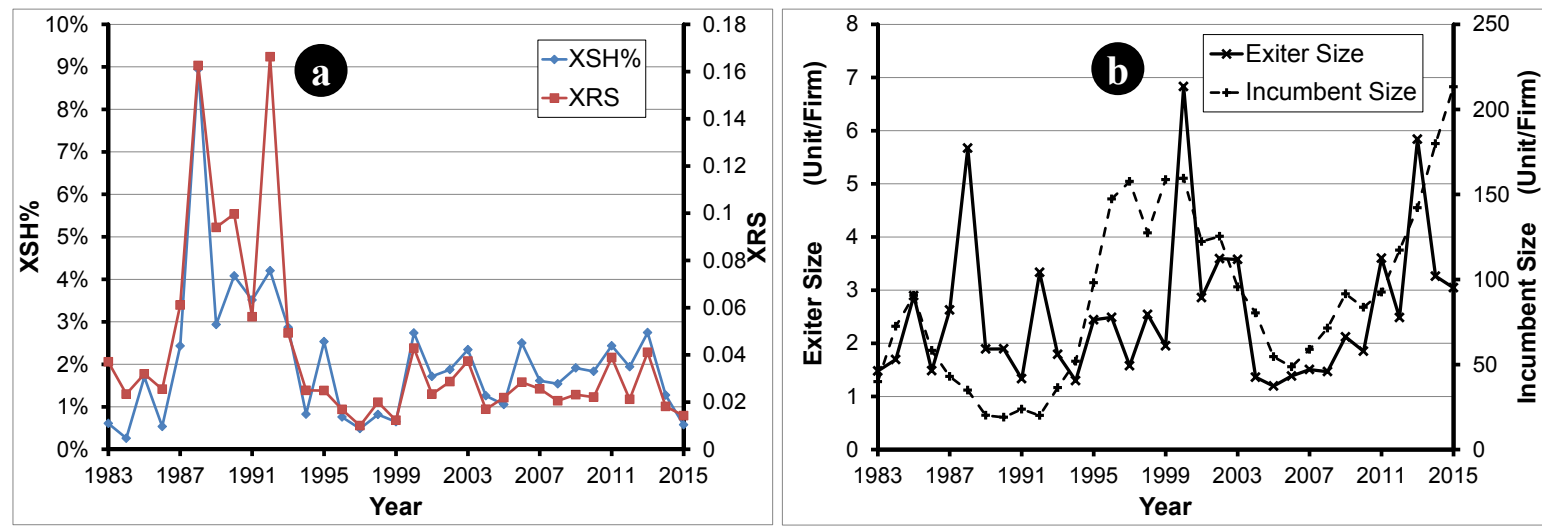

Figure 4. Characteristics of manufactured home market exiters in Texas: a) exiters' share (ESH) and their relative size (ERS); b) size comparison between exiters and incumbents. 


\section{Remarks on Observed Market Competition Metrics}

It was observed that the manufactured housing industry in Texas has experienced imperfect competition that favours local Texan manufacturers, despite the high mobility of manufactured homes. This conclusion is supported by the following observations:

- The manufactured home supply is majorly covered by local Texans manufacturers, who are usually fewer in number than foreign manufacturers from out of Texas. This implies a great deal of monopoly control by Texan firms for the local state market of manufactured homes.

- The product mobility of manufactured homes allows higher number of entrants and entry rate for foreign manufacturers, as shown in Figure 1. However, the size and supply magnitude of the foreign entrants is minimal compared to local incumbent manufacturers, as shown by their relative sizes $\left(E R S_{t}\right)$ and supply share $\left(E S H_{t}\right)$ in Figure 2.

- Foreign manufacturers suffer higher market exit rates (average 22.3\%) compared to local Texan manufacturers (average 12.8\%), as shown in Figure 3. This observation implies that local manufacturers enjoy a more stable market with higher competitiveness.

- Most of the exiting manufacturers have smaller sizes relative to remaining incumbents (i.e. low $X R S_{t}$ ) and marginal contribution to the total supply of Texas's manufactured housing supply (i.e. low $X S H_{t}$ ), as shown in Figure 4. This observation further supports the conclusion that Texas's manufactured housing market is characterized with imperfect competition.

\section{ANALYSIS OF MARKET DEMAND ATTRIBUTES}

The demand attributes of Texas's manufactured housing market are analysed to study the evolution of manufactured home requirements and the correlation between demand and inventory volumes.

First, physical requirements of the manufactured homes were examined by tracking the change of the average area and weight of the modular home sections between years 1982 and 2015. Both the average area and weight of home sections increased over the years, but at difference paces. The average home section area increased from 824 SF (square feet) in 1982 to 980 SF in 2015, which represents a change of $18.8 \%$. On the other hand, the average weight of home sections increased from around 16,000 $\mathrm{lb}$ (pounds) in 1982 to 24,500 $\mathrm{lb}$ in 2015, which represents a change of 52\%. Such large increase in the home section weight implies improved quality standards of manufactured homes as a result of using better insulation material, aesthetic finishes, and home equipment. However, the average area of the home sections witnessed smaller increases $(18.8 \%)$ due to the hard transportation constraints imposed by fixed highway lane widths. As such the average weight of every square feet of manufactured homes has increased from $19.6 \mathrm{lb} / \mathrm{SF}$ in 1982 to $25 \mathrm{lb} / \mathrm{sf}$ in 2015, which represents a $28 \%$.

Second, the data was used to analyse the relation between the demand volume of manufactured homes and their inventory time to observe how manufacturers and home dealers react to varying market conditions. Manufactured homes are usually supplied from the manufacturers to the customers through dealers, who buy the homes of standard models and stock them until the sale and installation time. As such, the inventory time of each home is calculated data as the time difference between its manufacturing and sale dates. Figure 5 depicts the charts of the average inventory times of sold manufactured homes and the number of home licenses over the years between 1982 and 2015. The charts clearly show a strong negative correlation between the number of new home licenses and their inventory time. This is due to the fact that higher housing 
sale volumes reduce gradually the number of home in inventory with dealers and manufacturers, which results in shorter inventory times. Manufacturers react to high sale volumes by increasing their production and supply of new homes. However, the end of the demand cycle and the decline of home sales results in increasing the number of homes stored with the dealers, and accordingly increase their inventory time. The shortest observed inventory time was found to be 35 days in 1983, while the longest inventory time of 340 days was observed in 2004.

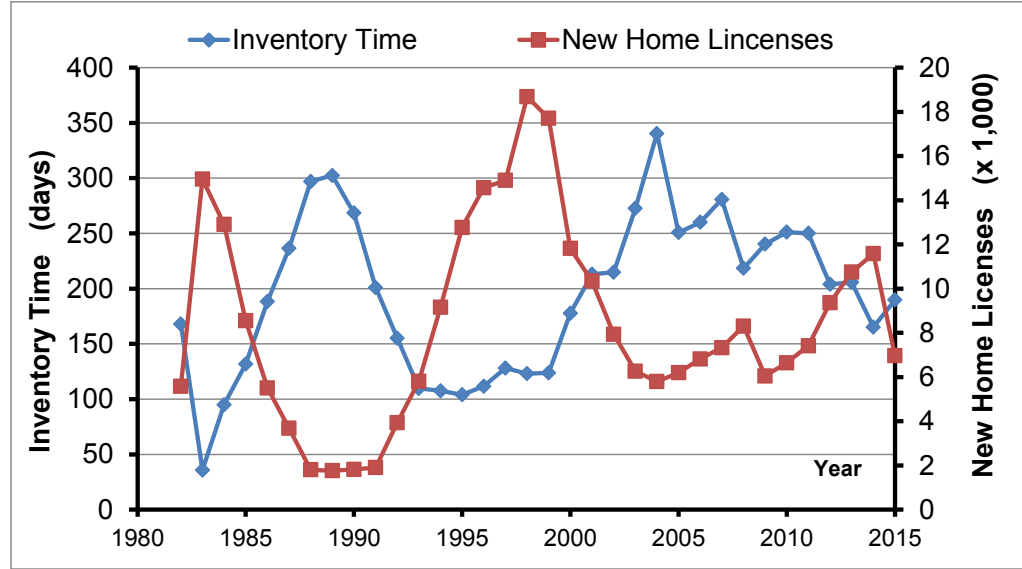

Figure 5. Relation between new manufactured homes sale (licenses) and market inventory time.

\section{CONCLUSION}

This paper summarized the findings of a preliminary study of manufactured housing market competition and demand attributes using micro licensing data of Department of Housing of Texas. The competition of the manufactured housing market was assessed using descriptive metrics to compare between the entry and exit of local (Texan) and foreign (out of Texas) manufacturers into the Texas manufactured housing market. Analysed demand attributes included the physical specifications of manufactured homes and relation between their demand volume and inventory time. The major lessons learned and findings of this study include: a) imperfect competition controls the regional markets of manufactured housing as local manufacturers contribute the most to the homes supply and suffer less exit from the market; $b$ ) the mobility of manufactured home help foreign manufacturers to enter the competition in neighbour regional markets, which is usually possible in time of high housing demand; 3) the quality of manufactured homes have improved over the last decades as shown by their increased geometric dimensions and weights; and 4) long inventory times were observed for the sampled manufactured homes, which increase with the decline of housing market demand.

\section{REFERENCES}

Abu Hammad A., Salem O., Hastak M., and Syal M. (2008). "Decision Support System for Manufactured Housing Facility Layout." Journal of Architectural Engineering. ASCE, 14, 36-46.

Barriga E., Jeong J., Hastak M. and Syal M. (2005). "Material Control System for the Manufactured Housing Industry.” Journal of Management in Engineering. ASCE, 21 (2005) 91-98.

Center for Housing Research (CHR) (2000). Industrializing the Residential Construction Site. Report prepared for the U.S. Department of Housing and Urban Development, Virginia Polytechnic 
Insititute and State University, Blacksburg, Virginia. Available online < https://www.huduser.gov/portal/publications/manufhsg/ircs.html> last accessed: 6/2/2016.

Dunne T., Roberts M. J., and Samuelson L. (1988), "Patterns of firm entry and exit in U.S. manufacturing industries," RAND Journal of Economics, Vol. 19, No. 4, pp. 495-515.

Einav L. and Levin J. (2010), "Empirical Industrial Organization: A Progress Report," Journal of Economic Perspectives 24(2):145-162.

Geroski P. (1995), "What do we know about entry?" International Journal of Industrial Organization, 13(4), 421-440.

Jeong J., Hastak M. and Syal M. (2006). "Supply Chain Analysis and Modeling for the Manufactured Housing Industry." Journal of Urban Planning and Development. 132, 1-9.

Mehrotra N., Syal M., and Hastak M. (2005). "Manufactured Housing Production Layout Design." Journal of Architectural Engineering. ASCE, 11, 25-34.

National Association of Home Builders (NAHB) (1998). Factory and Site-Built Housing - A Comparison for the 21st Century. Report prepared for the U.S. Department of Housing and Urban Development, NAHB Research Center Inc., Upper Marlboro, MD, available online $<$ http://www.huduser.org/Publications/pdf/factory.pdf > last accessed: 6/20/2016.

Nahmens I. and Bindroo V. (2011). "Is Customization Fruitful in Industrialized Homebuilding Industry?" Journal of Construction Engineering and Management, ASCE, 137, 1027-1035.

Prieger J. and Connolly M. (2013). "A Basic Analysis of Entry and Exit in the US Broadband Market, 2005-2008" (2013). Pepperdine University, School of Public Policy Working Papers. Paper 42. $<$ http://digitalcommons.pepperdine.edu/sppworkingpapers/42 $>$.

U.S. Census Bureau (USCB) (2013-a). Placements of New Manufactured Homes by Region and Size of Home: 1974-1988. <http://www.census.gov/construction/mhs/placed.html/quarterly $>$.Last accessed: 4/8/2016.

U.S. Census Bureau (USCB) (2013-b). Placements of New Manufactured Homes by Region: 1980 2012. < http://www.census.gov/construction/mhs/placed.html $>$. Last accessed 12/8/2013.

U.S. Census Bureau (USCB) (2013-c). Manufactured Home Production by State: $1990-2015 .<$ http://www.census.gov/construction/mhs/historical_data.html $>$. Last accessed 12/8/2013.

U.S. Department of Housing and Urban Development (US-HUD) (1994). Alternative Framing Materials in Residential Construction: Three Case Studies. Office of Policy Development and Research, Instrument No. DU100K00005911, Prepared by NAHB Research Center, Upper Marlboro, MD.

U.S. Department of Housing and Urban Development (US-HUD) (1998). Factory and Site-Built Housing - A Comparison for the 21st Century. Report prepared by NAHB Research Center for U.S. Department of Housing and Urban Development.

U.S. Department of Housing and Urban Development (US-HUD) (2000). Industrializing the Residential Construction Site. Office of Policy Development and Research, Center for Housing Research, Blacksburg, VA.

U.S. Department of Housing and Urban Development (US-HUD) (2001). Industrializing the Residential Construction Site - Phase II. Office of Policy Development and Research, Center for Housing Research, Blacksburg, VA.

U.S. Department of Housing and Urban Development (US-HUD) (2002). Technology Roadmap: Advanced Panelized Construction. Office of Policy Development and Research, Prepared by NAHB Research Center, Upper Marlboro, MD.

U.S. Department of Housing and Urban Development (US-HUD) (2003). Eliminating Barriers to the Use of HUD-Code Housing in Attached Construction. Report prepared by Manufactured Housing Research Alliance for U.S. Department of Housing and Urban Development.

Vermeer K. and Louie J. (1997). The Future of Manufactured Housing. Report R97-1, Joint Center for Housing Studies, Harvard University, < http://www.jchs.harvard.edu/research/publications/futuremanufactured-housing $>$, last accessed: 6/20/2016. 